\title{
ANTIMICROBIAL AND CYTOTOXIC ACTIVITIES OF MYRTUS COMMUNIS L.
}

\section{MYRTUS COMMUNIS L.'İN ANTIMIIKROBIYYAL VE SITOTOKSIK AKTIVİTELERİ}

\author{
Tuba MERT ${ }^{1 *}$, Tuğçe FAFAL ${ }^{1}$, Bijen KIVÇAK ${ }^{1}$, H. Tansel ÖZTÜRK ${ }^{2}$ \\ ${ }^{1}$ Ege University, Faculty of Pharmacy, Department of Pharmacognosy, 35100 Bornova, İzmir, \\ TURKEY \\ ${ }^{2}$ Ege University, Faculty of Science, Section of Biology, Department of Basic and Industrial \\ Microbiology, 35100 Bornova İzmir, TURKEY
}

\begin{abstract}
The antimicrobial and cytotoxic activities of n-hexane, methanol, ethanol, ethyl acetate and water extracts of Myrtus communis L. leaves were evaluated in this study. The antimicrobial activities of the extracts were reported against Escherichia coli ATCC 29998, Escherichia coli ATCC 25922, Escherichia coli ATCC 11230, Staphylococcus aureus ATCC 6538P, Staphylococcus aureus ATCC 29213, Staphylococcus epidermidis ATCC 12228, Salmonella typhimurium CCM 5445, Enterobacter cloacae ATCC 13047, Enterococcus faecalis ATCC 29212, Pseudomonas aeruginosa ATCC 27853 as bacteria and Candida albicans ATCC 10239 as yeastlike fungi by disc diffusion method. All of the extracts inhibited the growth of Escherichia coli ATCC 29998, Escherichia coli ATCC 11230, Staphylococcus epidermidis ATCC 12228, Salmonella typhimurium CCM 5445 and Pseudomonas aeruginosa ATCC 27853. The growth of Escherichia coli ATCC 25922 was only inhibited by the methanol extract. None of the tested extracts showed activity against Enterobacter cloacae ATCC 13047, Enterococcus faecalis ATCC 29212 and Candida albicans.

Cytotoxic activity of the extracts was tested in vitro against Brine shrimp. Cytotoxicity was evaluated by brine shrimp lethality bioassay. All of the extracts showed cytotoxic activity against brine shrimp.

Key Words: Myrtus communis L., Myrtaceae, Cytotoxic activity, Antimicrobial activity.
\end{abstract}

\footnotetext{
* Correspondence
} 


\section{ÖZET}

Bu çallşmada, Myrtus communis L.'nin n-hekzan, metanol, etanol, etil asetat ve su ekstrelerinin, antimikrobiyal ve sitotoksik aktiviteleri değerlendirildi. Ekstrelerin antimikrobiyal aktiviteleri, bakteri olarak Escherichia coli ATCC 29998, Escherichia coli ATCC 25922, Escherichia coli ATCC 11230, Staphylococcus aureus ATCC6538P , Staphylococcus aureus ATCC 29213, Staphylococcus epidermidis ATCC 12228, Salmonella typhimurium CCM 5445, Enterobacter cloacae ATCC 13047, Enterococcus faecalis ATCC 29212, Pseudomonas aeruginosa ATCC 27853 ve mantar olarak Candida albicans ATCC 10239 ' a karşl disk difüzyon metodu ile tayin edildi. Ekstrelerin tümü, Escherichia coli ATCC 29998, Escherichia coli ATCC 11230, Staphylococcus epidermidis ATCC 12228, Salmonella typhimurium CCM 5445 ve Pseudomonas aeruginosa ATCC 27853 üzerinde etkili olmuştur. Escherichia coli ATCC 25922 üzerinde ise sadece metanol ekstresi etki göstermişstir. Enterobacter cloacae ATCC 13047, Enterococcus faecalis ATCC 29212 ve Candida albicans üzerinde ise hiçbir ekstre etkili olmamıştır.

Ekstrelerin sitotoksik aktiviteleri Brine shrimp yöntemiyle değerlendirildi. Ekstrelerin hepsi Brine shrimp'e karşı sitotoksik aktivite gösterdi.

Anahtar Kelimeler: Myrtus communis L., Myrtaceae, Sitotoksik aktivite, Antimikrobiyal aktivite.

\section{INTRODUCTION}

Myrtus communis L. (Myrtaceae), commonly known as Myrtle, is an evergreen shrub widely distributed in Europe, Asia, Africa and America $(1,2)$. The plant have been used internally as astringent, antimicrobic, for constipation, antihemorrhagic, appetizing, against diabetes and externally for wound healing in Turkish folk medicine (2).

This plant is found to be rich in polyphenolic compounds such as flavonoids and tannins (3, 4). Phytocemical studies about M. communis showed also presence of essential oil (5).

The essential oil obtained from the leaves is mainly used in the treatment of lung disorders and has been found the posses antibacterial, antilouse, anti Helicobacter pylori and antimutagenic (6-11).

Several studies have found anti-inflamatory, anti-hyperglycemic and antioxidant activities in various extracts of this plant (12-15).

Many plants from the Myrtaceae family are reported to have antibacterial or antifungal activities (16).

Nevertheless, no report about the cytotoxicity of this plant is found in the literature. The extracts prepared from the leaves of M. communis is investigated for antimicrobial and cytotoxic 
activities for the first time in this study. The only literature data on antimicrobial activity of M. communis is given by Ilcim, whereas the only chloroform extract of M. communis was evaluated in this previous report (17).

On the basis, the aim of this work was to investigate the possible inhibitory activity of M. communis extracts against various microorganisms and to evaluate the cytotoxicity against Brine shrimp.

\section{MATERIALS AND METHODS}

\section{Plant material}

Myrtus communis L. was collected from Kemalpaşa (Izmir) in Turkey. The plant was identified by B. KIVÇAK. A voucher specimen was deposited in the Herbarium of the Department of Pharmacognosy, University of Ege (1265).

\section{Preparation of plant extracts}

Air dried and powdered leaves of Myrtus communis L. (20 g) were extracted with $200 \mathrm{ml}$ of the each following solvents, $n$-hexane, ethanol, methanol, ethyl acetate and water (infusion) at room temperature; the extracts were evaporated to dryness in vacuo and weighed.

\section{Cytotoxic studies}

Cytotoxicity was studied by Brine shrimp (Artemia salina) assay (18). Cytotoxic activity of all extracts were compared with umbelliferone and colchicine as the active cytotoxic substances $(19,20)$.

\section{Materials}

Brine shrimp was obtained from San Fransico Bay Brand Inc. Newark, CA94560 USA. Sea salt (Sigma-9883) were used in activity tests.The small tank was purchased from Otsuka Pharmaceutical Co.Ltd. (Tokyo, Japan).

\section{Method}

Cytotoxicity studies

Cytotoxicity was evaluated by the Brine shrimp lethality bioassay (18). The sea salt (3.8g) was dissolved in $100 \mathrm{ml}$ water and filtrated. Brine shrimp (Artemia salina) eggs were placed in to the sea water and allowed to incubate for $48 \mathrm{~h}$ at $28^{\circ} \mathrm{C}$ in a small tank. Each extracts were tested at 1000, 100 and $10 \mathrm{ppm} .20 \mathrm{mg}$ plant extract was dissolved in $2 \mathrm{ml}$ of chloroform to 
prepare a stock solution of $10 \mathrm{mg} / \mathrm{ml}$. From the stock solution, 500,50 and $5 \mu 1$ was transferred to different vials and allowed to evaporate. After evaporation, $5 \mathrm{ml}$ of sea salt solution was added to each vial to prepare concentrations corresponding to 1000, 100 and $10 \mathrm{ppm}$. Each concentration was prepared in triplicate. Also, a vial including chloroform $(500 \mathrm{ml})$ was prepared for control. After incubation, 10 Brine shrimp larvae (nauplii) were introduced into vials containing graded concentrations (ranging from 10 to $1000 \mathrm{ppm}$ ) of the test extracts. After 24h, the number of surviving shrimps at each concentration of the extracts was counted and data was analysed with Finney Computer programme to determine the $\mathrm{LC}_{50}$ at $95 \%$ confidence interval.

\section{Antimicrobial studies}

The disc diffusion method, known as the Kirby Bauer method, was used the determine antimicrobial activities (21-23).

24 hour cultures containing $10^{8} \mathrm{cfu} / \mathrm{ml}$ of microorganisms were used and diluted with sterile distilled water to obtain equivalent to 0.5 Mc Farland's standards of turbudity. 24 hour cultures of the yeast were prepared in Saboraud Dextrose Broth to obtain $10^{7} \mathrm{cfu} / \mathrm{ml} .40 \mu 1$ of reconstituted crude extracts were absorbed on to the sterile $6 \mathrm{~mm}$ discs (Oxoid Antibacterial Suspectibility Blank Tests Disc) under aseptic conditions to obtain $30 \mu \mathrm{g}$ extract/disc and dried at $50^{\circ} \mathrm{C}$. Dried discs were transferred on to the plates containing test organisms with sterile forceps. Control disc contained $40 \mu \mathrm{l}$ of sterile $10 \%$ aqueous DMSO. Agar plates containing bacteria were incubated at $37^{\circ} \mathrm{C}$ for $24 \mathrm{~h}$ and those containing yeast at $27^{\circ} \mathrm{C}$ for $48 \mathrm{~h}$. The standard antibacterial agent Ceftazidime (30 $\mu \mathrm{g} / \mathrm{disc})$ was used as a positive control for bacteria and the standard antifungal agent Nystatin ( $25 \mu \mathrm{g} /$ disc $)$ was used as the positive control for yeast. All experiments were done in triplicate.

\section{Test Microorganisms}

The following Gram (+) and Gram (-) bacteria were used for testing antibacterial activity.

Escherichia coli ATCC 29998, Escherichia coli ATCC 25922, Escherichia coli ATCC11230, Staphylococcus aureus ATCC 6538P, Staphylococcus aureus ATCC 29213, Staphylococcus epidermidis ATCC 12228, Salmonella typhimurium CCM 5445, Enterobacter cloacae ATCC 13047, Enterococcus faecalis ATCC 29212, Pseudomonas aeruginosa ATCC 27853 were used as bacteria and Candida albicans ATCC 10239 as yeastlike fungi.

Lyophilised bacteria and yeast were obtained from the Standart ATCC bacteria strain and Standart ATCC fungus strain collection of Department of Basic and Industrial Microbiology, Faculty of Science, Ege University. 


\section{Media}

The solid growth medium used for bacteria was Mueller Hinton Agar (Oxoid) and for yeastlike fungi was Saboraud Dextrose Agar (Difco).

All these microorganisms were obtained from Department of Basic and Industrial Microbiology, Faculty of Science, Ege University.

\section{RESULTS AND DISCUSSION}

Cytotoxic activity of $n$-hexane, ethanol, methanol, ethyl acetate and water extracts of the leaves of Myrtus communis L. have been investigated in vitro against Brine shrimp (Artemia salina). The results were reported in Table 1.

All of the extracts showed cytotoxic activity against Brine shrimp $\left(\mathrm{LC}_{50}<1000\right)$. Ethyl acetate and $n$-hexane extracts have exhibited more cytotoxic activity than the other tested extracts. These extracts were even more active than a cytotoxic substance umbelliferone (19), but they were less active than colchicine (20).

Table 1. Cytotoxicity assay of Myrtus communis L extracts against Artemia salina

\begin{tabular}{|l|l|l|l|l|}
\hline Extracts & $\begin{array}{c}\text { Concentration } \\
(\mathrm{ppm})\end{array}$ & $\begin{array}{c}\mathrm{LC}_{50} \\
(\mu \mathrm{g} / \mathrm{ml})\end{array}$ & $\mathrm{SD}(\%) \mathrm{n}=3$ & $\%$ Capacity \\
\hline Methanol & $1000: 100: 10$ & 13.7418 & 0.92 & 11.1 \\
\hline$n$-Hexane & $1000: 100: 10$ & 0.1009 & 0.46 & 3.1 \\
\hline Ethanol & $1000: 100: 10$ & 21.7142 & 0.33 & 7.2 \\
\hline Ethyl acetate & $1000: 100: 10$ & 4.2536 & 0.59 & 2.3 \\
\hline Water & $1000: 100: 10$ & 37.1540 & 0.21 & 9.7 \\
\hline Colchicine (Standard) & $500: 50: 5$ & 0.0009 & & \\
\hline Umbelliferone (Standard) & $500: 50: 5$ & 377.0223 & & \\
\hline
\end{tabular}

Results from the antimicrobial screening tests were shown in Table 2. As clearly seen in Table 2, the growth of Staphylococcus aureus ATCC 6538P and Staphylococcus aureus ATCC 29213 were more inhibited by the whole extracts than Ceftazidime. 
Table 2. Antimicrobial activity of Myrtus communis L. extracts

\begin{tabular}{|l|l|l|l|l|l|l|l|l|}
\hline & \multicolumn{5}{|l}{ Inhibition Zone (mm)* } & \multicolumn{5}{|l|}{} \\
\hline Microorganisms & A & B & C & D & E & F & G & H \\
\hline Escherichia coli ATCC 29998 & 8 & 8 & 9 & 9 & 9 & 15 & - & - \\
\hline Escherichia coli ATCC 25922 & - & - & - & 8 & & 14 & - & - \\
\hline Escherichia coli ATCC 11230 & 8 & 8 & 8 & 9 & 8 & 18 & - & - \\
\hline Staphylococcus aureus ATCC 6538P & 15 & 21 & 18 & 16 & 15 & 12 & - & - \\
\hline Staphylococcus aureus ATCC 29213 & 15 & 20 & 17 & 15 & 15 & 13 & - & - \\
\hline Staphylococcus epidermidis ATCC 12228 & 8 & 9 & 8 & 8 & 8 & 12 & - & - \\
\hline Salmonella typhimurium CCM 5445 & 7 & 8 & 7 & 8 & 7 & 14 & - & - \\
\hline Enterobacter cloacae ATCC 13047 & - & - & - & - & - & 13 & - & - \\
\hline Enterococcus faecalis ATCC 29212 & - & - & - & - & - & 11 & - & - \\
\hline Pseudomonas aeruginosa ATCC 27853 & 8 & 9 & 7 & 8 & 8 & 22 & - & - \\
\hline Candida albicans ATCC 10239 & - & - & - & - & - & - & 18 & - \\
\hline
\end{tabular}

A : Ethanol extract ; B : $n$-Hexane extract ; C : Ethyl acetate extract ; D : Methanol extract ; E : Water extract ; F : Ceftazidime ; G : Nystatine ; H : Control (DMSO ); * Includes diameter of disc ( $6 \mathrm{~mm}$ ).

All of the extracts inhibited the growth of Escherichia coli ATCC 29998, Escherichia coli ATCC 11230, Staphylococcus epidermidis ATCC 12228, Salmonella typhimurium CCM 5445 and Pseudomonas aeruginosa ATCC 27853. The growth of Escherichia coli ATCC 25922 was only inhibited by the methanol extract. None of the tested extracts showed activity against Enterobacter cloacae ATCC 13047, Enterococcus faecalis ATCC 29212 and Candida albicans.

However, the standard antibacterial agent, Ceftazidime, inhibited the growth of all of the tested microoorganisms but had no effect on the growth of $C$. albicans. On the other hand, the standard antifungal agent, nystatine, inhibited the growth of C. albicans but had no effect on the growth bacteria. DMSO also did not effect the growth of any tested microorganisms.

Recently, it has been reported that the essential oil of M. communis is strongly active againts Salmonella typhimurium (24). In our study, all of the extracts showed weakly activity against $S$. typhimurium.

The only literature data on the antimicrobial activity of M. communis L. has been given by Ilcim for the antimicrobial activity of the chloroform extract of $M$. communis L. (17). In this study, the chloroform extract was found to be highly active against S.aureus COWAN and Listeria monocytogenes SCOTT A. 
However, according to our results, the extracts of the leaves of this plants showed strongly activity against S. aureus ATCC 6538P and S.aureus ATCC 29213.

In conclusion, all of the extracts showed a range of activity against the tested bacteria and Brine shrimp. The antibacteriyal activity of the extracts against Staphylococcus aureus ATCC 6538P and Staphylococcus aureus ATCC 29213 was more than Ceftazidime . On the other hand, the most significant cytotoxic activity was found in $n$-hexane and ethyl acetate extracts. These results provide a support to some of the uses of the plant in Turkish folk medicine. Further studies are, therefore, needed to confirm its efficacy and to evaluate its safety.

\section{REFERENCES}

1. Polunin, O., Huxley, A., Flowers of the Mediterranean, Publications of Chatto and Windos Ltd., London, p. 285 (1972).

2. Baytop, T., Therapy with medicinal Plants in Turkey (Past and Present), Publications of the Istanbul University, No:3255, İstanbul, p. 326 (1984).

3. Sissi, H.I., Ansary, M.A. "Tannins and polyphenolics of the leaves of Myrtus communis" Planta.Med., 15, 41-51 (1967).

4. Martin, T., Rubia, B., Villaescusa, L., Fernandez, L., Diaz, A.M. " Polyphenolic compounds from pericarps of Myrtus communis" Pharmaceut. Biol., 37, 28-30 (1999).

5. Ozek, T., Demirci, B., Başer, K.H.C. "The chemical composition of Turkish Myrtle Oil” J. Essent. Oil Res., 12 , 541-544, ( 2000).

6. Gauthier, R., Agaumi, A., Gourai, M. "Active d'extrait de Myrtus communis contre pediculs humanus capitis" Phytotherapie, 23, 95-108 (1989).

7. Chevolleau, S, Debal, A., Ucciani, E. "Determination de l'activite antioxidante d'extraits vegetaux" Rev. Fr. Corps Gras., 1, 3-8 (1993).

8. Hayder, N., Kilani, S., Abdelwahed, A., Mahmoud, A., Meftahi, K., Chibani, J., Ghedira, K., Chekir-Ghedira, L. "Antimutogenic activity of aqueous extracts and essential oil isolated from Myrtus communis" Pharmazie, 58, 25-27 (2003).

9. Romani, A., Coinu, R., Carta, S., Pinelli, P., Galardi, C., Vincieri, F.F., Franconi, F. "Evaluation of antioxidant effect of different extracts of Myrtus communis" L. Free Radic. Res., 38, 97-103 (2004) 
10. Atapour, M., Javad Zahedi, M., Mehrabani, M., Safavi, M., Keyvanfard, V., Foroughi, A., Siavoshi, F., Foroumadi, A. "In vitro susceptibility of the Gram-negative bacterium Helicobacter pylori to extracts of Iranian medicinal plants" Pharmaceut. Biol., 47,1, 77-80 (2009).

11. Hayder, N., Skandrani, S., Kilani, S., Bouhlel, I., Abdelwahed, A., Ammar, R.B., Mahmoud, A., Ghedira, K., Chekir-Ghedira, L. "Antimutagenic activity of Myrtus communis L. using the Salmonella microsome assay” JS. Afr. Bot., 74, 121-125 (2008)

12. Hayder N., Abdelwahed, S., Kilani, R., B.,Ammar A., Mahmoud K., Chekir-Ghedira L. "New alpha-glucosidase inhibitors and antibacterial compounds from Myrtus communis L." Mutat. Res., 564, 89-95 (2004).

13. Romani A., Coinu R., Carta S., Pinelli P., Galardi, C., Vincieri, F. F., Franconi F. “ Evaluation of antioxidant effect of different extracts of Myrtus communis L". Free Radic. Res., 38,97-103 (2004).

14. Bonjar G.,H. "Antibacterial Activity Of Plants Used In Iranian Herbal-Medicine" Fitoterapia, 75,231-235 (2004).

15. Rosa A., Deiana M., Casu, V., Corona, G., Appendino, G., Bianchi F., ballero M., Dessi M., A. “Acylphloroglucinols from Myrtus communis L.” Free Radic. Res., 37, 1013-1019 (2003).

16. Sabahi M., Mansouri S., Ramazenian M., Gholamhoseinian A. "Screening of plants from the southeast of Iran for antimicrobial activity" Int J. Crud. Drug Res., 25, 72-76 (1987).

17. Ilcim, A., Digrak, M., Bagci, E. "Bazı bitki ekstraktlarının antimikrobiyal etkilerinin araştırılması" Turk. J. of Biol., 22 ,119-122 (1998).

18. MacLaughlin, J.L.,Chang, C.J.,Smith, D.L. in ,Studies in Natural Products Chemistry, in Attaur- Rahman (Ed.), Elsevier Science Publishers B.V., Amsterdam, Vol. 9, 383- 409 (1991).

19. Jimenez O. F.A., Molina G.J.A., Mendoza P. N., Leon C.F., Flores P. B., Santos S. E., Mandoki I.J. "Cytostatic activity of coumarin metabolites and derivatives in the B-16-F-10 murine melanoma cell line" Melanoma Res. , 9, 243-247 (1999).

20. Lee, K.H. “ Novel antitumor agents from higher plants" Med. Res. Revi. , 19, 569-596 (1999). 
21. Collins, C.M., Lyne, P.M., Microbiological Methods, Butterworths Co. (Publishhers) Ltd., London, p. 56-69 (1987).

22. Performance Standarts for Antimicrobial Disc Suspectibility Tests. Approved Standard NCCLS Publication $\mathrm{M}_{2}-\mathrm{A}_{5}$, Villanova, PA, USA (1993).

23. Gür, D., Antibiyotik Duyarlılık Testleri: Antibiyotiklere Direnç Mekanizmaları ve Antibiyotik Duyarlılık Testleri, in E.H. Akalın (ed), Pfizer İlaçları A.Ş. Kitaplar Serisi, İstanbul, p. 45-67 (1992) .

24. Gündüz G. T., Gönül Ş. A., Karapınar M. "Efficacy of Myrtle oil against Salmonella typhimurium on fresh produce" Int. J. Food Microbiol., 130, 147-150 (2009).

Received: 13.01 .2010

Accepted: 23.02 .2010 